\title{
SOCIAL ELITES AND THEIR COMPETENCE. CRISIS OR EXCESSIVE EXPECTATION?
}

\author{
Ta deusz O leksyn* \\ Perception is not the privilege of scientists, \\ it is in all our interests. \\ Ludwig von Mises
}

\begin{abstract}
The following subject matter of social elites has been undertaken here: what they were in the past and what they are today, how they are formed and what their key competences are. There shall also be a concise description of the chosen theories of the elite: Vifredo Pareto, Max Weber, Robert Michels, Gaetano Mosci, James Burnham, Peter F. Drucker, Wright Milles, Roberta D. Putnam, and Zygmunt Bauman. The subject matter of these brief deliberations shall be elitarian and egalitarian policies, while also the negative consequences of excessive elitarian and egalitarian policies. The key competences of the social elites shall be reviewed as exemplified by several chosen functions and positions.

Let us consider the issue of the crisis of the elite - the scale, the causes, and counteractions. The accusations that the elite is failing us are not new. Every once in a while this happens in different locations and on varying scales. The role and possibilities of the elite are often over-estimated; the replacement of the imperfect elite with something much worse also happens. It is an open issue as to whether all the intricate and difficult problems (of a specific organisation, country, or the world) are solvable; a positive response to such questions would seem to be more than optimistic. Perhaps the expectations with regard to the elite, as well as towards management are excessive and unrealistic. Such a view is opined by Charles Handy and Henry Minzberg, albeit politicians, particularly authoritarians and populists, would never be brave enough to openly admit that they are not almighty and their electorate would never accept such information.

In a democratic system, a legal state, an entrepreneurial society and in conditions of the prevailing natural/spontaneous order over artificial and contrived order, the elite encompasses significantly more valuable and active people than in authoritarian, centralised, and hierarchical systems. The elites of a democratic and civic society are also usually safer for people and more efficient in terms of action than the elites
\end{abstract}

\footnotetext{
* University of Finance and Management in Warsaw, e-mail: tadeuszoleksyn@gmail.com
} 
in authoritarian states or hybrid democracies. There are a multitude of examples of this both in historical and contemporary times.

Key words: social elites, competences, elitarianism, egalitarianism, civil society

\section{INTRODUCTION}

The beginning of the $21^{\text {st }}$ century is characterised by, among other aspects, the crisis of trust towards the elite in a multitude of countries. This phenomenon appeared on a broader scale during the world economic crisis of 2007 that emerged in the USA and later spread almost all over the world. As a result of state interventionism and the cost of the huge rise in the public debt in many countries, enterprises from not only the financial and banking sector were not allowed to go bankrupt. Both the crisis and the manner of its resolution and consequences were a sign for a multitude of people that the world economic and financial elites, as well as multiple top managers did not stand up to the challenge. Questions relating to the competences of these people became valid, both in professional and moral terms, as well as the assumptions and form of globalisation.

The looming third world war, in the words of Pope Francis, gives rise to questions about the competences of the political and military elites. It is indeed clear that the elites are not coping with the limitation of threats and resolution of problems, while the policies applied are incohesive and inefficient.

In fact, we are also dealing with a third great problem, namely that of contesting the liberal democracy and civic society, the growth of populism, nationalism, demagoguery, and demanding attitudes in a certain number of countries that until recently seemed to have been convinced about democracy. In Hungary, Poland, and the USA the elections were won by such a force, while the growing acceptance for these directions of change is visible in several other countries. Such a great and noble world experiment as the EU, by living in peace without borders is seriously under threat, which has become even more obvious following Brexit.

A fourth great problem is that of the overburdening of the natural environment of the planet by as much as $60 \%$ in the opinion of Dennis Meadows (2014), which in turn gives rise to a more specific threat to the life and health of people, as well as the majority of other creatures. 
Additionally, it may also render economic growth impossible, while even lead to an economic crash in the weaker countries first.

It is possible and indeed necessary to pose the question here as to what extent the elites are failing and where the cause lies in terms of scale and the accumulation of very difficult problems. Perhaps they are not solvable in not only the short term, but in a longer term perspective too, in which case the problem lies not only among the elites. Perhaps the main cause is not to be found in the elites at all.

The aim of this paper is to indicate reflections, as well as an attempt at a synthesis associated with the chosen subject matter. An attempt at answering the following questions shall be undertaken:

1. What is, and how does the role of elites look in comparison with the past?,

2. What are the positive and negative sides of elitarianism/elitism and egalitarism?

3. What are, and how should the ties and relations of the elites be with the "rest of society"?

The following research methods have been adopted: comparative analysis, historical analysis, literary study, synthesis, induction, and deduction. The approach is intended as interdisciplinary. With regard to the huge differentiation of the situations in various countries and regions of the world, it is difficult to define to what extent, if at all possible to refer to the value of the universality of observations and conclusions. This is first and foremost a viewpoint in a discussion that is a current topic that is important to everyone. A comprehensive and integrated scientific research program on a global scale and in all these dimensions is obviously not feasible due to the labour intensity and costs. Thus, it is also possible to refer to the disappointment that the scientific elites have caused in some sense.

\section{Understanding the notion of social elites}

The term social elites is not unequivocal. At this juncture we shall adopt the positive definition (T.O.) in that the social elites are people that provide a particular society with direction in terms of pursuits and development, which are usually acknowledged to be trustworthy by way of their authority and other attributes, while also the existing moral values and merits. The direction provided by the elites may relate to various areas as follows: politics, science, education, culture, fine 
arts, religion, defence, judiciary, public administration, diplomacy, etc. In a narrower sense, which is associated with the notion of elitism and the elite theory, they are most frequently restricted to the spheres of politics, economics and business, while also military (more seldom) and the entities directly associated with them (think-tanks, foundations, outstanding experts - advisors, etc.).

The conviction of the necessity and benevolence of the existence of the elites in society and the state bears the name of elitarianism or elitism (Dutkiewicz, 2012, p. 175). This is not a widespread conviction, albeit prevalent.

The social elites are synonymous with the higher class, which is also an ambiguous notion that is perceived in varying degrees in various countries and in various epochs. In the past, the higher classes were in particular the following: aristocracy, spiritual hierarchy, brilliant scholars and thinkers, as well as propagators, rulers and influential politicians, outstanding military leaders, outstanding people of the arts, judges, and parliamentarians/deputies. Since the industrial revolution, the social elite also relates to industrialists and other significant entrepreneurs, while since the 1940s professional managers, especially top managers. The term elite is often used with relation to the genome and health of a man, as well as the particular psycho-physical possibilities of among others, excellent sportsmen and soldiers.

In the interwar period of Poland, the notion of intelligence was significant and perceived in a way that is rather similar to the modern-day elites. An intelligent person was a person who had completed secondary school education as there were very few such people at that time: only a few thousand up to little over ten thousand people graduated from secondary school with a diploma nationwide annually; in the school year of 1933-1934 fewer than 15,000 graduates (Concise Statistical Year Book of Poland, 1936, section XVIII, table 19). A good pre-war grammar school probably had ambitions in the sphere of the universality of education, general culture, and views of its graduates were significantly higher than the majority of modern-day schools as the level of importance of the school leaving certificate was incomparably higher than today.

Alongside the social elites there is another term of celebrities which is of a differing meaning, namely people that frequently appear in the mass media and who arouse the greatest level of interest of both the media sources, as well as the people who avail of them. 
Celebrities are most often famous artists and people of show business, outstanding actors, sportsmen, journalists and participants of reality-shows. Synonymous terms: stars, fame, idols. This paper does not relate to celebrities.

"The study of elites is the study of power and ineguality. It involves looking at the distribution of social resources, which can include economic, social, cultural, political or knowledge capital" (Khan, 2012).

\section{ELITE THEORY}

The elite theory, also called elitism, most frequently restricts the elites to the political, economic, and business environments that exercise real power. The classic elite theory states that in a positive variant the elites are formed by people who are particularly intelligent and capable of governing, while exercising their ruling authority for the good of the majority that is incapable of ruling itself. This is how the elites were perceived in the classic theory of elites by the Italian economist Vilfredo Pareto (1848-1923), who was of the opinion that the elites had a psychological and intellectual advantage over the rest of society. Pareto distinguished the ruling elites (exercising real power) and non-governing (not taking direct decisions and not running politics, yet exerting influence on the position of science, counselling, as a lobby group, etc.). Nevertheless, Pareto did not narrow the elites down to only people with ties with governing - in a direct and indirect sense. Likewise, he also opined that "entry to the elite" is a high level of efficiency and effectiveness of activities and not a sense of belonging to a specified social class or political party. He created the model of the circulation of the elite, illustrating in what manner the elite is exchanged and replaced.

Pareto distinguished elites between those, who resembled the lion (domination by force) and those who resembled the fox (domination by persuasion and skill); a typology that resembles Machiavelli's political philosophy (Lopez, 2013).

A German sociologist that lived in similar times, Max Weber (1864-1920) who was a theorist of management, political scientist, and historian, was of the same opinion as Pareto that the ties of the elites and social classes are neither necessary nor decisive. Belonging to the elite should be decided by personal competences and efficiency 
in terms of thinking and action. Weber created the theory of bureaucracy, which in his times did not have a pejorative hue (every large organisation was then termed bureaucracy). He connected the rapid growth of capitalism and development of civilisation with Protestantism (particularly Calvinism), in opposition to Catholicism, which was questioned much later. A multitude of Weber's other principal theories were also questioned and the negative impact of a range of his theories on ruling practices and style of ruling were also questioned - but that is another issue. In his era, Weber enjoyed great respect and was extraordinarily opinion-forming.

The German sociologist, Robert Michels (1876-1936), the creator of the "iron law of the oligarchy", contributed the viewpoint to the theory of elitism that bureaucracy (as a type of organisational culture) inevitably leads to oligarchy. Even organisations that were initially idealistic and democratic in this type of organisations become over time dominated by small groups of people that are guided by self-interest. These people care about maintaining their positions, but not the greater good. This is so widespread that as Michels noted - whoever says organization [bureaucratic], says oligarchy (Tolbert, 2010). It is possible to perceive this statement as being very pessimistic, yet it is also possible to view it as a voice against bureaucratic organizations.

The Italian lawyer, sociologist, political scientist and historian, Gaetano Mosca (1858-1941) deemed that the elites are organised minorities, while the rest of society is the disorganised majority. The elites have intellectual, tangible, and moral advantage over the majority, which is badly received, particularly when the majority is subjected to manipulation and bad treatment. Incidentally, Mosca was the creator of the notion "political class", which is often applied in Poland.

A professor of sociology at the New York University, a high-ranking official of the CIA and the author of the renowned book entitled Managerial Revolution (1941), James Burnham (1905-1987) initiated the era of managerism in the USA and worldwide, albeit his theory (also partly ideology) was initially badly received. It was the time of not only World War II, but also intense rivalry in terms of the shape of the world of the future between the democratic and the totalitarian systems. Burnham propagated the view that the professionalisation of management would help the Western world to win this race, while simultaneously to form a new elite - that of professional managers. 
They shall play a leading role not only in the economy, but also in a multitude of other areas of life. Managers shall become more important than politicians and more important than capital owners, while capitalism itself will become managerial capitalism. The managerial competences were of key significance here as the driving forces of progress, development of civilisation, growth, and improvement in the standard of living.

The second precursor of the managerial revolution and also the "pope of contemporary management" was that of Peter F. Drucker, an American of Austrian origin, a man of wide interest and huge knowledge. He gained renown by research conducted in the General Motors concern in the 1940s that was to provide answers to the question of what managers actually do and how management looked in their activities. Drucker wrote 13 books on management, of which each brought him a lot of renown, while he was also an influential business consultant and professor of management at several universities. To a significant degree, the inspiration provided by these two people led to the rapid formation of a wide educational market (thousands of business schools and management all over the world), a range of publishing houses publishing millions of copies of books and articles on the subject of management, while also the development of business consultancy. Worldwide management noted a multitude of successes, while top-managers did in fact become the social elite and frequently very wealthy people. In time, they started to reveal the weaker sides of managerism (everything has weaker sides). Nevertheless, up to now there has been no alternative to managerism, even if the position of managers in the modern-day world is over-valued.

The author of a strongly opinion-forming book entitled the Elite of power, the American sociologist Wright Mills (1916-1962), described the post-war system of power in the USA as a "triumvirate of the elite of business, politics and the army". The aforesaid triumvirate constitutes in his opinion a relatively narrow, closed, and demoralised group. Mills stated that it is a similar case in a multitude of other countries. The main conclusion that he formulates is that democracy is degrading itself, while the real power depends on elective representatives to a small extent (Wiki, theory of elites, accessed January 14, 2017). It is possible to add that the elective representatives of the society are capable of effectively destroying democracy as it turned out in Poland quite recently, without even a hint of shame. 
Robert D. Putnam (born in 1941), professor of Harvard University, specialising in public policy, indicates the rising influence of the competences of experts and specialists of policies and the decisions of politicians in his works, which is nothing bad generally speaking. Likewise, he also draws attention to the significance of social capital for economic development and success. He notes that in northern Italy where the level of capital is high, the region is flourishing with a high level and dynamics of growth. There is a multitude of chambers of industry and commerce located there, as well as merchant and trade guilds, various socio-occupational clubs and associations where people can frequently meet, exchange information and may consult on various ideas and socialise. In the agrarian and rural south of Italy, where social capital is low and additionally destroyed by the mafia, the situation is radically worse as there are vast differences between the north and the south of Italy. It would seem that the factor of social capital should be taken into consideration in Poland too with the reduction of the differences between the so-called Poland A and Poland B. We have a major problem with the "break-up" of the Polish society into two parts, which are increasingly moving apart from each other. A large portion of the blame lies with the politicians of the ruling party who came to power by exposing and deepening these divisions, while also contesting the liberal parliamentary democracy and that of the EU.

The outstanding Polish sociologist and philosopher, Prof. Zygmunt Bauman (1925-2017), who had been associated with Great Britain since 1971, was particularly interested in post-modernism in the latter part of his life, which he more frequently termed post-modernity, late modernity or liquid modernity. Greater attention was placed by him on the weaknesses of post-modernism than its strong points. With regard to the elites, he particularly drew attention to the phenomenon of the blurring of the powers that be and that of responsibility, or indeed their disappearance ("Who is flying the plane?"). Additionally, he pointed out the fact that as opposed to the prevalent rhetoric - "those, who were to rejoice in freedom are hesitant to take it", in which "the truth, which was supposed to liberate is frequently what people prefer not to hear" (Bauman, 2006, p. 30). This may partly explain the ambivalent approach to liberalism, in which freedom (including individuals) is the most highly rated value - but, probably not by all. Freedom is also risk and personal responsibility, while for many it may be acknowledged to be excessive burden and stress. Demagogic 
politicians, who successfully create the illusion that they can ensure safety and success to people in every sense of the word, are the ones that achieve success in the elections.

\section{UNIVERSAL COMPETENCE OF PEOPLE}

Regardless of the profession executed, it is possible to distinguish the following universal competences of people that are important from the viewpoint of their professional activity and the results of their activities. These competences may be grouped into sets as presented in Table 1.

Table 1. Universal competences of people associated with their professional activity

\begin{tabular}{|l|l|l|}
\hline No. & Set of universal competences & \multicolumn{1}{|c|}{ Clarification } \\
\hline 1. & $\begin{array}{l}\text { Talents/abilities and predispo- } \\
\text { sition }\end{array}$ & $\begin{array}{l}\text { It is assumed that talents are more seldom } \\
\text { and more valuable than abilities; they are not } \\
\text { expected everywhere. }\end{array}$ \\
\hline 2. & Internal motivation and pursuit & They are more appreciated in 21st century. \\
\hline 3. & Education and knowledge & $\begin{array}{l}\text { In general, they are strongly correlated with } \\
\text { each other, although there are outstanding } \\
\text { self-learners without diplomas and college } \\
\text { graduates without knowledge. }\end{array}$ \\
\hline 4. & $\begin{array}{l}\text { Professional practice and experi- } \\
\text { ence (personal experience also) }\end{array}$ & $\begin{array}{l}\text { They are not expected everywhere. In the past } \\
\text { few decades they have lost their significance } \\
\text { relatively speaking. }\end{array}$ \\
\hline 5. & $\begin{array}{l}\text { Intelligence and personality } \\
\text { features }\end{array}$ & $\begin{array}{l}\text { Different work and occupations require vari- } \\
\text { ous personality features, intelligence is almost } \\
\text { always present. }\end{array}$ \\
\hline 6. & Attitudes and behaviour & Not always officially formulated. \\
\hline 7. & Social and ethical competences & As above. \\
\hline 8. & $\begin{array}{l}\text { State of health and psychophysi- } \\
\text { cal condition }\end{array}$ & Frequently under-appreciated. \\
\hline
\end{tabular}

Source: Oleksyn, 2018, pp. 37-39.

Eight of the afore-mentioned groups of competence in total constitute the attributes of human capital.

Some roles require leadership abilities and predisposition. These also include universal competences as indicated in Table 1. This is illustrated in Table 2 as exemplified by the competences expected from the CEO (Chief Executive Officer) in a large corporation in Table 3 on the basis of the example of the leader of a party that acknowledges democratic order. 
Table 2. Expected competences of the CEO as exemplification of universal competences

\begin{tabular}{|c|c|c|}
\hline No. & $\begin{array}{l}\text { Set of universal } \\
\text { competences }\end{array}$ & Detailed competences of the CEO \\
\hline 1. & $\begin{array}{l}\text { Talents/abilities and } \\
\text { predisposition }\end{array}$ & $\begin{array}{l}\text { - leadership } \\
\text { - imagination, strategy } \\
\text { - correct selection of co-workers } \\
\text { - efficiency }\end{array}$ \\
\hline 2. & $\begin{array}{l}\text { Internal motivation and } \\
\text { pursuit of: }\end{array}$ & $\begin{array}{l}\text { - management } \\
\text { - successes }\end{array}$ \\
\hline 3. & $\begin{array}{l}\text { Education } \\
\text { and knowledge }\end{array}$ & $\begin{array}{l}\text { - higher-level studies, prestigious college with good } \\
\text { results most preferably } \\
\text { - knowledge of areas of science of management } \\
\text { - familiarity with sector and market, law, and good } \\
\text { practices }\end{array}$ \\
\hline 4. & $\begin{array}{l}\text { Professional practice } \\
\text { and experience }\end{array}$ & $\begin{array}{l}\text { - previous experience and successes in managerial } \\
\text { work }\end{array}$ \\
\hline 5. & $\begin{array}{l}\text { Intelligence and person- } \\
\text { ality features }\end{array}$ & $\begin{array}{l}\text { - distinguishing intelligence } \\
\text { - consistency of actions and pursuit of goals } \\
\text { - effectiveness }\end{array}$ \\
\hline 6. & Attitudes and behaviour & $\begin{array}{l}\text { - consistency of actions and pursuit of goals } \\
\text { - civil courage and bravery }\end{array}$ \\
\hline 7. & $\begin{array}{l}\text { Social and ethical com- } \\
\text { petences }\end{array}$ & $\begin{array}{l}\text { - integrity and ethicality } \\
\text { - goodwill towards other people } \\
\text { - culture } \\
\text { - assertiveness }\end{array}$ \\
\hline 8. & $\begin{array}{l}\text { State of health and psy- } \\
\text { chophysical condition }\end{array}$ & $\begin{array}{l}\text { - generally good state of health and good psychophys- } \\
\text { ical condition } \\
\text { - healthy lifestyle } \\
\text { - free of addictions }\end{array}$ \\
\hline
\end{tabular}

Source: own elaboration.

As the managers of higher and lower levels work with people and via people, the correct selection of the closest co-workers is still significant, namely to have "a lucky hand" for people. Conrad Hilton, the founder of the famous hotel chain, when asked about the secret to his success replied: "select the best co-workers, place them in the key positions and give them a free hand". If they are better than you in a specified area (and they should be), you should not direct them as you will do it worse than them. An extremely rich American industrialist of Scottish descent from the $20^{\text {th }}$ century, Andrew Carnegie, ordered the following to be engraved on his gravestone: Here lies a man who surrounded himself with those better than himself (Poissand, 1993). Selecting mediocre, but obedient people around you is not the way to success. 
Table 3. Expected competences of the leader of a democratic political party

\begin{tabular}{|c|c|c|}
\hline No. & $\begin{array}{l}\text { Set of universal } \\
\text { competences }\end{array}$ & Detailed competences \\
\hline 1. & $\begin{array}{l}\text { Talents/abilities and } \\
\text { predisposition }\end{array}$ & $\begin{array}{l}\text { - leadership } \\
\text { - imagination and strategy } \\
\text { - outstanding abilities in the sphere of communication } \\
\text { - great selection of co-workers } \\
\text { analysis and synthesis and logical conclusions }\end{array}$ \\
\hline 2. & $\begin{array}{l}\text { Internal motivation and } \\
\text { pursuit of: }\end{array}$ & $\begin{array}{l}\text { - creating a better world } \\
\text { - resolving significant political and social problems }\end{array}$ \\
\hline 3. & $\begin{array}{l}\text { Education and knowl- } \\
\text { edge }\end{array}$ & $\begin{array}{l}\text { - higher-level studies, prestigious college with good } \\
\text { results most preferably } \\
\text { - knowledge of areas of political science, economics, } \\
\text { history of sociology, social psychology, and law } \\
\text { - familiarity with organisation of the state and its } \\
\text { institutions } \\
\text { - familiarity with the European Union, its aims and } \\
\text { values, structures, principles of activities, and } \\
\text { organisation }\end{array}$ \\
\hline 4. & $\begin{array}{l}\text { Professional practice } \\
\text { and experience }\end{array}$ & $\begin{array}{l}\text { - previous experience and successes in organisational } \\
\text { work and with people } \\
\text { - tried and trusted skill of unifying followers and } \\
\text { exerting influence }\end{array}$ \\
\hline 5. & $\begin{array}{l}\text { Intelligence and person- } \\
\text { ality features }\end{array}$ & $\begin{array}{l}\text { - distinguishing intelligence } \\
\text { - moderation and balance } \\
\text { - ensistency of actions and pursuit of goals } \\
\text { effiveness }\end{array}$ \\
\hline 6. & $\begin{array}{l}\text { Attitudes and be- } \\
\text { haviour }\end{array}$ & $\begin{array}{l}\text { - responsibility and predictability of behaviour } \\
\text { - familiarity and respect for principles of democracy } \\
\text { and law (international and national) } \\
\text { - "hard when faced with problems, soft when faced } \\
\text { with people" } \\
\text { - consistency of actions and pursuit of goals, but also } \\
\text { flexibility (not dwelling in mistakes) } \\
\text { civil courage }\end{array}$ \\
\hline 7. & $\begin{array}{l}\text { Social and ethical com- } \\
\text { petences }\end{array}$ & $\begin{array}{l}\text { - integrity, ethicality } \\
\text { - goodwill towards other people } \\
\text { culture }\end{array}$ \\
\hline 8. & $\begin{array}{l}\text { State of health and psy- } \\
\text { chophysical condition }\end{array}$ & $\begin{array}{l}\text { - generally good state of health and good psychophys- } \\
\text { ical condition } \\
\text { - healthy lifestyle } \\
\text { - free of addictions }\end{array}$ \\
\hline
\end{tabular}

Table 3 is obviously of a wishful nature - not even a virtual one.

Source: own elaboration.

The expectations related to the leader of a political party should be very high with additional regard to the fact that the leader of the party that achieves success in the elections usually becomes the prime minister and this signifies the necessity to possess additional 
and significant competences, the more so as the modern-day world in the era of globalisation and "knowledge society" is very complicated.

The lack of mechanisms securing the society against insane rulers and politicians is surprising in a literal sense and also a contemporary sense despite the multitude of tragic experiences over the centuries. The "lust for power" of many paranoid people is well-known and well-described; which refers to the biggest war criminals in the history of the world - Hitler and Stalin.

There are virtually no competence requirements that are placed before people exercising power by way of election apart from possessing the citizenship of the particular country at hand and no criminal record (This has been in implementation only in the recent past. Hitler was able to take power despite being convicted of a military coup).

\section{PROS AND CONS OF THE CONCEPT WITH KEY ROLE OF THE ELITES}

The idea that the social elites are essential and fulfil a key role has both good sides and bad sides. This is undergoing a certain evolution. Indeed, this would seem to be common sense, while also in accordance with the social division of labour: some build houses, others transport goods, some others govern and everyone knows something else. However, this is not entirely true.

Arguments in favour are as follows:

- Authentic elites form in the process of natural selection, development, and rivalry of people of high potential (human capital). This leads to the case whereby only the best are on the top of the social ladder, those who have exerted the greatest impact, provide direction, contribute new values, and constitute a role model to be followed by others.

- Not everyone can govern. The majority of people are incapable of this for various reasons as follows: they do not have such potential, they do not have such aspirations, they do not have the desire (to even vote in an election). If everyone was to decide, there would be chaos and large conflicts.

- The egalitarian concept, opposed to the elite is demotivating, demanding, as well as leading to ineffectiveness and "equal distribution of poverty"). 
Arguments against are the following:

- The very idea of the "social ladder", at the top of which must be some form of "elite", is very controversial, bureaucratic, caste, and undemocratic.

- $\quad$ Either civic society, or the elite.

- The elites degenerate and degrade rapidly. In theory, they were supposed to be composed of the best, whereas in practice they frequently consist of their own, bought, dependent, "passive, mediocre but faithful" (BMW).

- The elites often appropriate everything that is important and lucrative for a long time. Due to this fact, nepotism and corruption flourish, cliques are formed, while the majority becomes marginalised.

\section{Compromise variant:}

- The elites are created in a natural way, in conditions of free competition protected by law. The elites are created spontaneously, in accordance with objective and fair principles represented by people who actually are the best.

- Not all the elective positions are under the obligation of terms of office which cannot be evaded.

- Clarity and logical transparency, as well as fair principles and criteria are binding, while everything takes place "under a raised curtain" and is controlled by the "fourth power".

- Rebuilt and separated civil services. The politicians at the head of administrative posts only provide a certain political colouring as they do not decide about everything, especially in terms of personnel policies.

- Good laws and good practices are binding; international standards are adhered to.

Compromise variant - between the exaggerated elite and the egalitarian - these are in essence the principles of liberal democracy and the state law that are now being destroyed by the current government in Poland.

\section{CRISIS OF THE ELITES?}

Universal competences of the social elites are first and foremost abilities, knowledge and intellect, creativity, skill of analysis and synthesis, instinct and intuition, skill of reading the "signs of the times", while 
also the personality attributes. The factors that are contributed to the elites are most frequently in real democracies and open societies such as great advantages, significant successes, personal contribution to the development of civilisation, the skill of resolving important problems and creating progress, limiting threats, and providing hope in a credible manner.

The crisis of the elites and their belittling of such, which happens once in a while and which we may observe in modern-day times are mainly associated with their insufficient ability to lead effectively and efficiently, provide the appropriate direction and resolve problems. This crisis may be evoked or escalated by brutal criticism, dissent, revolutions, and profound transformation that lead to the replacement of the elite. Likewise, the crisis of the elites is also connected with the excessive expectations and disappointments against this backdrop: not all promises and expectations can be fulfilled, not all problems are (entirely) solvable, the endeavour to solve singular problems may lead to the generation of others, sometimes even worse ones. An objective contrast also exists between the autonomy of an entity, its pursuit of self-realisation and being the "architect of your own destiny", while also depending on the elites that repeatedly limit the freedom of people. The elites, especially political ones, are subject to the processes of degradation, "wear and tear", occupational burnout, and cynicism.

At the beginning of the $21^{\text {st }}$ century in many countries disappointment may be observed with regard to the political, economic, and financial elites, while also (albeit on a lower scale) managerial elites.

It is a debatable issue whether we are dealing with the crisis of science, or rather the breaking away from some of the illusions connected with it: in a secularised world, it adopted an over-valued position following the period of the Enlightenment. Nevertheless, life shows that not everything is possible (or will ever be). Apart from this fact, as correctly noted by Charles Handy, as opposed to common opinion, changes are too few rather than too many, whereas progress is made much more slowly than previously thought (Handy, 1994). This may even be exemplified by the Stanley Kubrick's film entitled Space Odyssey 2001. It was imagined in those times (1968) that inter-galactic travel would be commonplace by the end of the $20^{\text {th }}$ century. Now, we know that this will not happen in the foreseeable future. Likewise, we also know that we shall not be immortal on Earth (except parousia), nor shall we live 300 years or even "at least" 130 , in which prolonging life 
is principally prolonging old age. In truth, there are those that say: "If I cannot be eternally young, I would at least like to be eternally old". But this is not possible either.

Thus, we arrive at the final conclusion: the elites shall deteriorate more slowly, evoke less disappointments and anger if they refrain from the propagation of lies, illusions, and false promises. Hard times are approaching and have actually already arrived. In order to face them, it is necessary to utilise wisdom and truth and not myths and demagoguery. It is also important not to create illusions that everything is possible, that everything is at the will of a strong and centralised power. We have had that scenario before and it ended in disaster in various countries.

\section{ETHICAL ASPECTS}

Such terms as social elite, elitarianism, egalitarianism, while also the associated politics all have their own weight with regard to ethical dimensions and disputes that are usually charged emotionally.

Most frequently, both politics that is strongly elitarian, but also strongly egalitarian are not the most appropriate. Excessively strong elitarianism evokes shock among the majority of people and destroys social cohesion. Excessively strong egalitarianism is demotivating (discouraging efficient work) and demoralising - as the number of people is growing, who in the words of the brilliant economist, Prof. Jan Winiecki (1938-2016) "chcą żyć z ręką w cudzej kieszeni" (who want to live out of the pockets of others). A certain compromise or broader consensus is necessary as the viewpoints and convictions of people are strongly differentiated.

This is not easy as objectivity is in scarce supply. The individual assessment primarily depends on what social class a person belongs to and identifies with. Likewise, the question of who is to pay for the beneficiaries of such a system or any other system of supporting groups that are economically weaker is important - for instance, large families, homeless people and those in a bad situation in terms of housing, and those addicted to alcohol and other narcotics, etc, whether the people providing for all this have any say in the matter or not. If they have nothing to say and nobody even asks for their opinion, then this is also immoral. 
Social elites are more accepted as the access to them is open, thus in free and open societies where elites may interchange in a natural manner. The situation where a glass ceiling is widespread is unethical in which the positions and most significant organisational roles are reserved for the next of kin and friends of the owners or politicians. Likewise, the excessive growth in numbers of the elite via statism, bureaucracy, coalition contracts, and agreements for increasingly influential (and highly paid) positions, also in state treasury companies, etc. whereby such activities not only involve significant sums of money that are insufficient for other people that actually work efficiently, but also reduce the positions and level of satisfaction, while also the possibilities of action for specialists and managers of lower and medium levels by unnecessarily extending the pyramid of positions. They also reduce the autonomy of competent people.

\section{FINAL REMARKS}

Down through the ages social elites have generally played a significant role in the development of civilisation, as well as the fate of states and societies. It was expected that the elite would personify significant values and facilitate the right course of direction that is worth pursuing. People searched for charismatic leaders and bestowed them with their trust. They entrusted them with their fate which ended badly in some cases and was the cause of great misfortune.

Contemporary democracy and civil society signify a turn of action in the direction of a more rational and safe approach to social elites. Elites to a lesser extent are imposed, invariable, and arbitrary, while their power is restricted, controlled, and temporary. Almost everyone who possesses the appropriate advantages and is sufficiently determined and ready to undertake the specified difficulty has the opportunity to make it and achieve success, while becoming part of some social elite.

One of the significant conditions that should be fulfilled for the process of education and replacement of the elite to be conducted properly is freedom, while simultaneously adherence to the law and good practices. The ability to stop individuals with the exuberant desire for power and amoral, ruthless, and aggressive significance, coupled with an authoritarian personality, which is always pathological is significant. In every society there are such individuals and they create problems. 
In particular, these are the leaders of various criminal groups, the mafia, etc. that form a specific "black elite". There is always a danger that the political elite in an authoritarian system or hybrid system would "slip towards" the "black elite" - by breaking the law, permitting violation of human rights and deciding to undertake brutal action. In effect, not only the specified formations, such as the political police, censorship, the army and special services, but also entire political systems degenerate and gain a bad reputation.

One of the key problems is not to allow the excessive accumulation of power. This is served by not only the three-tiered power system proposed in the $18^{\text {th }}$ century by Montesquieu, but also respect for the autonomy of self-government, entrepreneurs, non-governmental organisations, the media, universities, trade unions, social and occupational organisations, and a multitude of others. It is best for development when a multitude of various elites exist and each of them enjoys significant freedom and autonomy.

It is equally important not to allow the appropriation of the state by political parties and the ideologisation of various fields of social life: the economy, science, culture, etc. This is always carried out to the detriment of themselves and society as a whole - including its elite.

\section{REFERENCES}

Bauman, Z. (2006). Ptynna nowoczesność. Kraków: Wydawnictwo Literackie.

Burnham, J. (1941). Managerial revolution. New York: John Day Co.

Dutkiewicz, G. (2012). O pojęciu i istocie zjawiska elit. Colloqium Wydziału Nauk Humanistycznych $i$ Społecznych, 3.

Handy, Ch. (1994). Niewyobrażalna przyszłość. Warszawa: Dom Wydawniczy ABC, https://pl.wikipedia.org/wiki/Teoria_elit [access: 10.11.2017].

Khan, S. (2012). The sociology of elites. Annual Review of Sociology, 38, 361-377, https://pl.scribd.com/document/261782882/KHAN-Shamus-rahman-theSociology-of-Elites-pdf [access: 10.11.2017].

Lopez, M. (2013). Elite theory, http://www.sagepub.net/isa/resources/pdf/Elitetheory. pdf [access: 10.11.2017].

Oleksyn, T. (2017). Zarzadzanie zasobami ludzkimi w organizacji, wyd. IV. Warszawa: Wolters Kluwer S.A.

Oleksyn, T. (2018). Zarzadzanie kompetencjami, teoria i praktyka, wyd. III. Warszawa: Wolters Kluwer. 
Poissand, Ch. (1993). Miliarderzy. Warszawa: Wydawnictwo Medium.

Szczupaczyński, J. (2013). Wtadza a moralny wymiar przywództwa. Warszawa: Dom Wydawniczy Elipsa.

Tolbert, P.S. (2010). Robert Michels and the Iron Law of Oligarchy, http://digitalcommons.ilr.cornell.edu/cgi/viewcontent.cgi?article=1404\&context=articles [access: 10.11.2017]. 


\title{
ELITY SPOKECZNE I ICH KOMPETENCJE. KRYZYS CZY ZA DUŻE OCZEKIWANIA?
}

\begin{abstract}
Abstrakt
W artykule podjęty został temat kompetencji elit społecznych pod kątem rozważenia kilku kwestii: rozumienia pojęcia „elity społeczne” - w przeszłości i dzisiaj, przeglądu wybranych teorii elit, kluczowych kompetencji elit społecznych (zwłaszcza elit menedżerskich, ekonomicznych i politycznych), a także hipotetycznego kryzysu elit - jego realności, symptomów, przyczyn i możliwego przeciwdziałania. To krótkie wyjaśnienie ukazuje zarazem cele, przyjęte w tym opracowaniu - poznawcze i badawcze.

Zarzuty, że elity zawodza, nie są nowe, a co jakiś czas powtarzają się ze zwiększoną siłą w różnych miejscach i skali. Prawdopodobnie są one w wielu przypadkach w jakimś stopniu prawdziwe, choć rola i możliwości elit bywają przeceniane. Z uwagi na rozległość tematu i mocno ograniczoną objętość wypowiedzi ma ona charakter syntetyczny.
\end{abstract}

Słowa kluczowe: elity społeczne, kompetencje, elitaryzm, egalitaryzm, społeczeństwo obywatelskie, demokracja, systemy demokratyczne, hybrydowe i autorytarne 